\title{
Outcome Evaluation of a Zero-Profile Implant for Anterior Cervical Diskectomy with Fusion
}

\author{
Füzyonla Anterior Diskektomi İcin Bir Sufir Profilli Implantın \\ Sonuçlarmmn Değerlendirilmesi
}

Waleed AZAB ${ }^{1}$, Mamdouh ABDEL-RAZEK ${ }^{1}$, Abeer ALI ${ }^{2}$, Ahmed ABDELRAHMAN ${ }^{1}$, Waleed SALAHELDIN ${ }^{1}$, Khurram NASIM ${ }^{1}$, Hosam ATTIA 3 , Doaa SOLIMAN ${ }^{4}$

${ }_{1}^{1}$ Ibn Sina Hospital, Department of Neurosurgery, Kuwait, Kuwait

${ }^{2}$ Ibn Sina Hospital, Department of Anaesthesia and Intensive Care, Kuwait, Kuwait

IIbn Sina Hospital, Department of Radiology, Kuwait, Kuwait

${ }^{4}$ Ibn Sina Hospital, Department of Neurology, Kuwait, Kuwait

Correspondence address: Waleed Abdelfattah AZAB / E-mail: waleedazab@hotmail.com

\begin{abstract}
AIM: Supplementing anterior cervical diskectomy and fusion (ACDF) with plates enhances stabilization, increases fusion and reduces failure rates. Zero-P implant for stand-alone anterior interbody fusion procedures of the cervical spine was recently developed to avoid complications associated with anterior cervical plates. We evaluate the outcome of its use in our patients undergoing ACDF.

MATERIAL and METHODS: 84 patients were selected to undergo ACDF with Zero-P implant of whom 75 (52 male and 23 female) were followed up for 12 to 16 months (mean 14.2 months) with a total of 94 operated levels ( 54 single, 21 double level). Patients underwent pre- and postoperative clinical evaluation with full neurological examination, visual analogue scale (VAS), Neck Pain and Disability Scale (NPAD) and Bazaz-Yoo dysphagia index for postoperative dysphagia. Postoperative plain X-ray evaluation of fusion and implant-associated complications was done.

RESULTS: All patients had significant reduction in arm and neck pain and NPAD maintained over 12 months, no implant-associated complications during follow-up, and radiological fusion by 3 months. None had dysphagia after 3 months postoperatively.

CONCLUSION: The Zero-P implant is a valid alternative to anterior cervical plating after ACDF with a very low incidence of postoperative dysphagia and no implant-related complications.
\end{abstract}

KEYWORDS: Anterior, Cervical, Diskectomy, Zero-profile, Plate, Dysphagia

öz

AMAÇ: Anterior servikal diskektomi ve füzyonu (ACDF) plakalarla desteklemek stabilizasyonu güçlendirir, füzyonu arttırır ve başarısızlık oranını azaltır. Anterior servikal plakalarla ilişkili komplikasyonlardan kaçınmak üzere yakın zamanda servikal omurganın tek başına anterior interbody füzyon işlemleri için Zero-P implantı geliştirilmiştir. ACDF yapılan hastalarımızda bu implantın kullanılmasının sonuçlarını değerlendirdik.

YÖNTEM ve GEREÇLER: Toplam 84 hasta Zero-P implantıyla ACDF yapılmak üzere seçildi ve bunların 75'i (52 erkek ve 23 kadın) $12-16$ ay (ortalama 14,2 ay) boyunca toplam 94 opere seviye ile (54 tek, 21 çift seviye) izlendi. Hastalara tam nörolojik muayene, görsel analog ölçek (VAS), Boyun Ağrısı ve Maluliyet Ölçeği (NPAD) ve postoperatif disfaji için Bazaz-Yoo disfaji indeksi kullanılarak preoperatif ve postoperatif klinik değerlendirme yapıldı. Ayrıca füzyonun ve implantla ilişkili komplikasyonların postoperatif röntgen değerlendirmesi gerçekleştirildi.

BULGULAR: Tüm hastalarda 12 ay boyunca devam edecek şekilde kol ve boyun ağrısı ve NPAD bakımından önemli azalma oldu, takip boyunca implantla ilişkili komplikasyon görülmedi ve 3 ay içinde radyolojik füzyon gerçekleşti. Ameliyattan 3 ay sonra hiçbirinde disfaji yoktu.

SONUÇ: Zero-P implantı ACDF sonrasında servikal plakalama için geçerli bir alternatiftir ve postoperatif disfaji insidansı çok düşük olup implantla ilişkili bir komplikasyon görülmemiştir.

ANAHTAR SÖZCÜKLER: Anterior, Servikal, Diskektomi, Sıfır profil, Plaka, Disfaji

\section{INTRODUCTION}

Since its introduction in 1955 by Smith and Robinson (30) and shortly thereafter by Cloward (11), anterior decompression of the spinal canal and foramina has been an accepted treatment of degenerative cervical disc disease (39). Several technical modifications have been developed since then, but no consensus regarding the optimal technique has been established (42).

Although the literature is replete with reports comparing interbody cages of different materials with autologous iliac bone grafting as a control $(19,29,38,39)$, and studies comparing simple anterior cervical diskectomy with cage- 
assisted interbody fusion (5), interbody fusion following anterior cervical diskectomy for treatment of cervical radiculopathy or myelopathy is thought by many authors to have several advantages compared with diskectomy alone (40). Controversy exists, however, regarding the optimal substrate for cervical fusion (43). The scarcity of randomized studies makes it difficult to establish a gold standard (39).

Supplementing fusion procedures with anterior cervical plating is thought to enhance stabilization with increased fusion and reduced failure rates $(14,36)$. The addition of a plate is, however, not without side effects including dysphagia and implant-associated complications (34).

Although the profile of current anterior plates is thinner than that of earlier designs, the plates are still somewhat bulky and may contribute to postprocedure dysphagia (34). The incidence of dysphagia after anterior cervical surgery ranges from less than $2 \%$ to greater than $50 \%(6,15,32,33,35,45)$.

Zero-P implant (Zero-P; Synthes GmbH Switzerland, Oberdorf, Switzerland) for stand-alone anterior interbody fusion procedures of the cervical spine was developed to potentially avoid complications associated with anterior cervical plating (34).Our center was one of the earliest centers in the middle east to have this implant available; we started using the Zero-P implant in 2009; and launched this study to evaluate the outcome of its use in our patients undergoing ACDF.

\section{MATERIAL and METHODS}

Between May 2009 and May 2010, 84 patients were selected to undergo ACDF for prolapsed cervical disks at levels from
C3-C4 down to C6-C7 that presented with a cervical radicular syndrome or neurological deficit with or without neck pain failing conservative treatment for at least 6 weeks and corresponding findings on magnetic resonance imaging (MRI) studies (Figure 1A-C). Nine out of the 84 patients were lost during follow up period. Patient selection criteria are represented in (Table I).

The patient population consisted of 52 male and 23 female patients with ages ranging from 22 to 66 years (mean, $43.2 \pm$ 9 years). A total of 94 levels were operated (54 patients with single and 21 with double level disease). The contribution of each cervical level to the total operated levels is represented in (Table II, Figure 2). Follow up periods ranged from 12 to 16 months (mean 14.2 months).

Preoperative clinical evaluation was done by a team comprising a neurologist, pain specialist and a neurosurgeon. This included a pre-operative full neurological examination and painful symptom quantification using visual analogue scale (VAS) of 0 to $100 \mathrm{~mm}$ (9), Neck Pain and Disability Scale (NPAD) of $0 \%$ to $100 \%$ (18) with thorough documentation of three cervical symptom clusters: 1) Neck pain, 2) Radicular pain, and 3) Neurological deficits.

Pre-operative radiological studies of the cervical spine included digital plain x-rays (anteroposterior, lateral, oblique and flexion/extension views) and magnetic resonance imaging (MRI) including T1 and T2-weighted sequences in both axial and sagittal planes.

A standard surgical technique for anterior cervical microdiskectomy was used $(4,17)$. In all patients a Zero-P

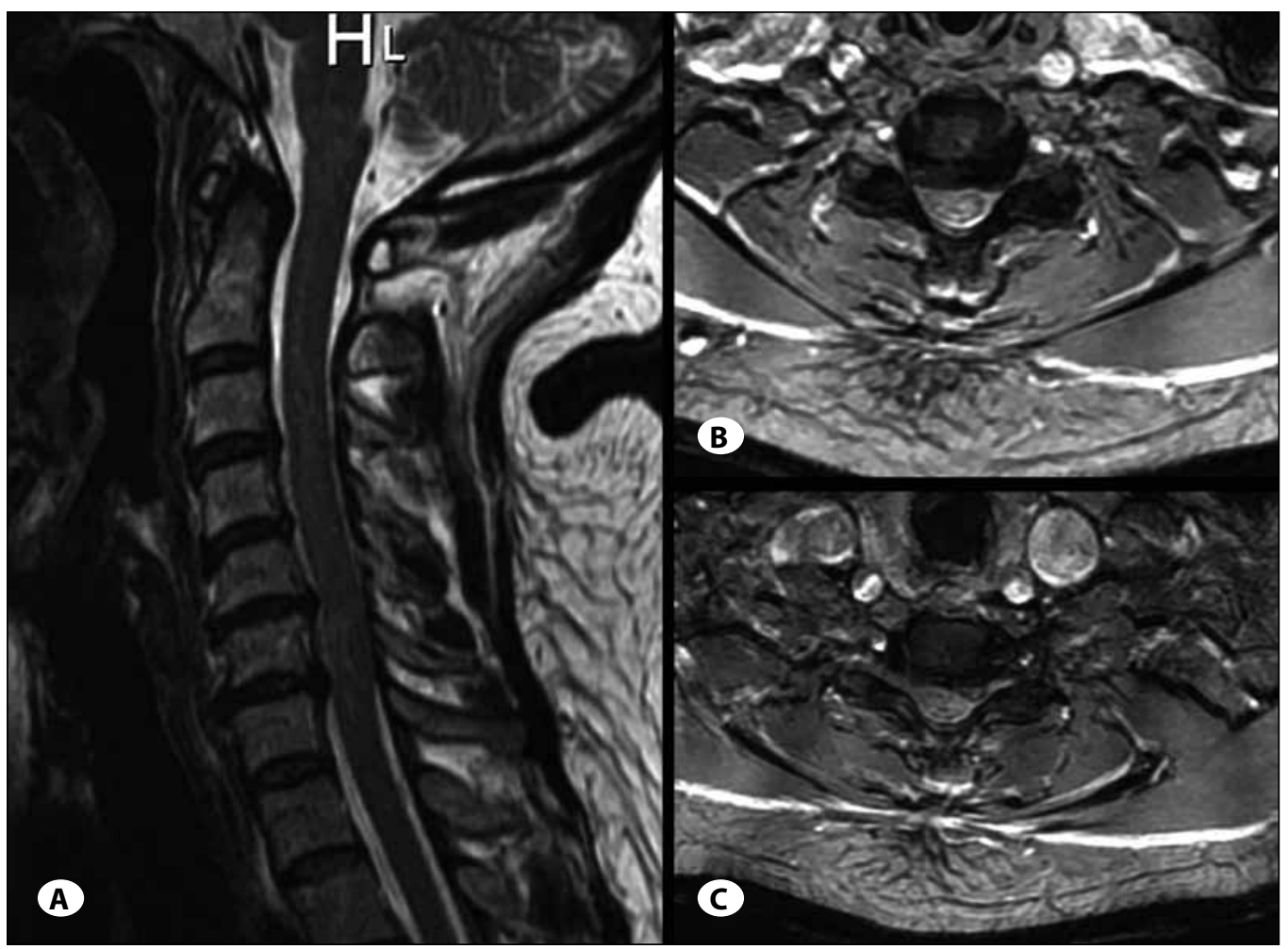

Figure 1: Preoperative $\mathrm{T}_{2}$-weighted MRI. A) Sagittal image reveals C5-6 and C6-7 disk prolapse. B-C) Axial images demonstrating disk prolapse at C5-6 and C6-7 levels respectively. 
Table I: Patient Selection Criteria

\section{Inclusion Criteria:}

1. Skeletally mature adult between the ages of $18-70$ years.

2. Symptomatic cervical disc disease at any vertebral level between C3-C7 with Neck or arm (radicular) pain and/or functional/neurological deficit confirmed by imaging MRI.

3. Has completed at least six (6) weeks of conservative therapy;

\section{Exclusion Criteria:}

4. Posterior instrumentation necessary at same level.

5. Previous surgery at the index level.

6. Fused level adjacent to the index level.

7. Active systemic or local infection including active hepatitis (receiving medical treatment within two years).

8. Active rheumatoid arthritis.

9. Immunologically suppressed, or has received systemic steroids, excluding nasal steroids, at any dose daily for $>1$ month within last 12 months.

10. Known history of Paget's disease, osteomalacia, or any other metabolic bone disease.

11. Osteoporosis with DEXA bone density measured T score $\leq-1.0$.

12. Morbid obesity defined as a body mass index $>40 \mathrm{~kg} /$ $\mathrm{m} 2$ or weight more than 100 pounds over ideal body weight

13. Active malignancy.

14. Current or recent history (within last 2 years) of substance abuse.

15. Pregnant or planning to become pregnant during study period.

16. History of psychosocial disorders that could prevent accurate completion of self reporting assessment scales.

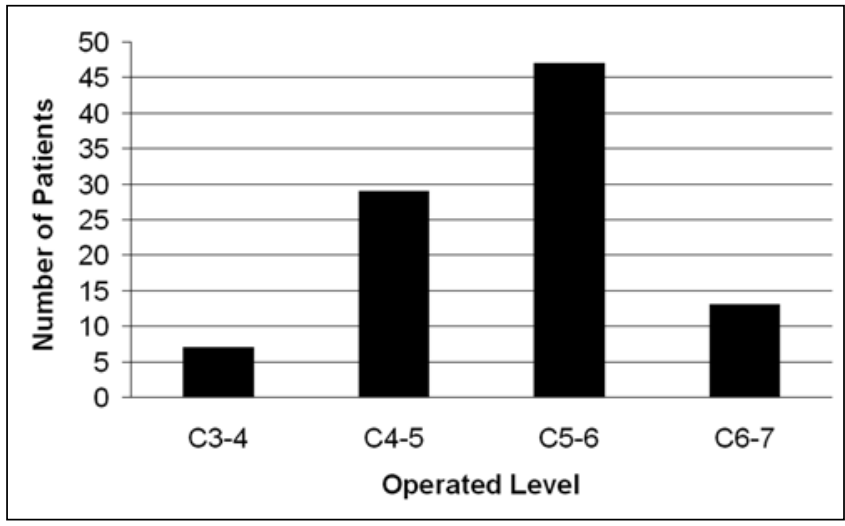

Figure 2: Bar graph representing the frequency of each cervical level to the total operated levels. implant (Zero-P; Synthes GmbH, Oberdorf, Switzerland) was used for fusion; the implant was filled with ß-tricalcium phosphate cylinder (chronOS cylinder; Synthes $\mathrm{GmbH}_{\text {, }}$ Oberdorf, Switzerland). Implant sizes used are represented in (Table III). Implantation technique is described elsewhere (34). No neck collars were used postoperatively.

Post-operative clinical outcome evaluation was undertaken immediately postoperatively then at 1.5, 3, 6, 9, 12 months and consisted of the same pre-operative clinical examinations and questionnaires in addition to Bazaz-Yoo dysphagia index (6) (Table IV). All complications were documented.

Post-operative radiological evaluation with plain radiographs of the cervical spine (anteroposterior, lateral and oblique views as well as dynamic views) immediately postoperatively then and at 1.5, 3, 6, 9, 12 months.

Differences between preoperative and postoperative VAS, NPAD-D scores were calculated using the Student's t-test for paired samples using SPSS ${ }^{\circ}$ software version 16.0.1.

\section{RESULTS}

All patients had a reduction in VAS radicular arm pain $(p<0.001)$, VAS neck pain $(p<0.001)$ and NPAD $(p<0.001)$ within the first 3 months (Figures 3,4$)$. We observed no change in VAS neck pain ( $p=0.518)$, VAS radicular arm pain $(p=0.739)$, and NPAD score $(p=0.273)$ comparing 3 and 12 months follow up. No statistically significant difference in outcome was found between male and female patients, between

Table II: Contribution of Each Level to the Total Operated Level

\begin{tabular}{|c|c|}
\hline Operated Level & Frequency $(\mathbf{n} .94)$ \\
\hline C3-4 & 7 \\
\hline C4-5 & 29 \\
\hline C5-6 & 47 \\
C6-7 & 13 \\
\hline
\end{tabular}

Table III: Zero-P Implant Sizes Used in the Study Population

\begin{tabular}{|c|c|c|}
\hline Implant Size & Frequency (n.96) & Percentage (\%) \\
\hline $5 \mathrm{~mm}$ & 16 & 17 \\
\hline $6 \mathrm{~mm}$ & 33 & 34 \\
$7 \mathrm{~mm}$ & 38 & 40 \\
\hline $8 \mathrm{~mm}$ & 9 & 9 \\
\hline
\end{tabular}

Table IV: The Bazaz-Yoo Dysphagia Index (6)

\begin{tabular}{|l|l|l|}
\hline Severity & Liquid & Solid \\
\hline 0 None & None & None \\
\hline Mild & None & Rare \\
2 Moderate & None or rare & $\begin{array}{l}\text { Occasionally with specific } \\
\text { food }\end{array}$ \\
\hline 3 Severe & None or rare & Frequent (majority of solids)
\end{tabular}


different age groups, between patients with soft versus hard disks or between patients harboring a single versus double level disease.

There was no implant subsidence or screw pullout during follow-up and all patients had radiological evidence of fusion by 3 months postoperatively (Figure $5 A, B$ ).

Among the study population, 39 of 75 patients (76\%) complained of mild dysphagia (Score1 on Bazaz-Yoo Dysphagia Index ) with symptom duration of $17 \pm 9$ days. At 6 weeks' follow-up, 8 patients (10.5\%) complained of mild dysphagia which resolved completely by 3 months in all of them.

We had one patient with hoarseness of voice that resolved in 8 months and one patient with superficial wound infection ( $2.7 \%$ complication rate).

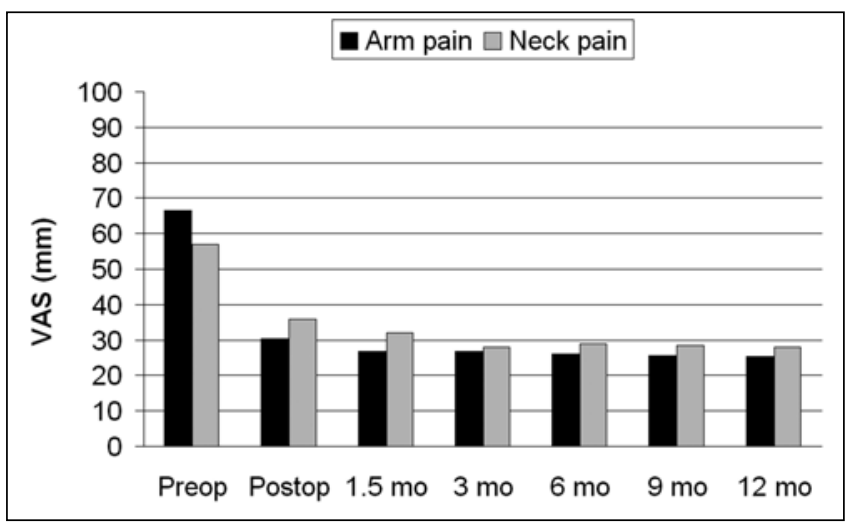

Figure 3: Bar graph of the pre- and post-operative arm and neck pain represented as a 0-100 $\mathrm{mm}$ VAS over the follow up period.

\section{DISCUSSION}

The ideal cervical fusion substitute should result in fusion in all patients and offer maximal comfort. It would avoid pain and associated soft tissue morbidity, obviate the need for cervical orthosis, and not impair subsequent radiological investigations. It would provide immediate stability in compression and resist axial displacement, minimize neck pain, and maintain spinal alignment and foraminal height (38).

Cervical cages are generally characterized by being small, porous, hollow, cylindrical or nearly cubical implants that are thought to restore physiological disc height and allow bone growth through the implant with consequent bony fusion (2). Cages were developed to prevent disc space collapse and decrease morbidity at the donor site which was reported

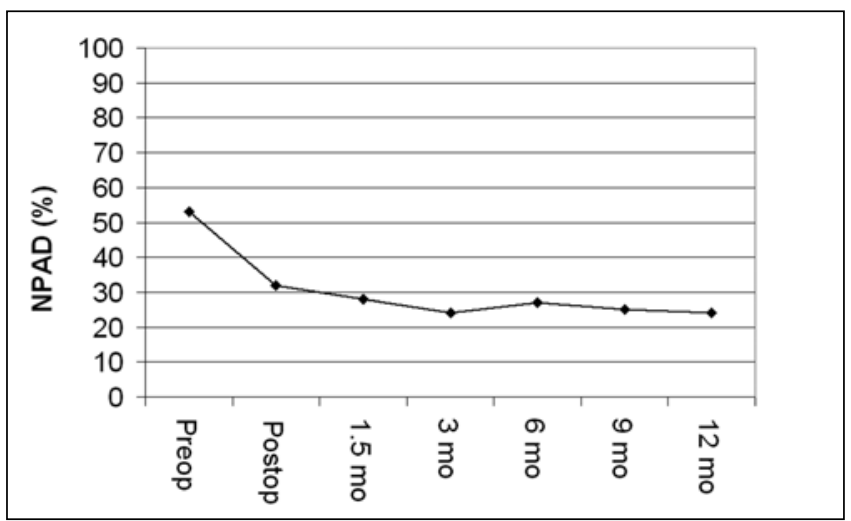

Figure 4: Graphic representation of the pre- and post-operative changes of the NPAD scores representing neck pain over the follow up period.
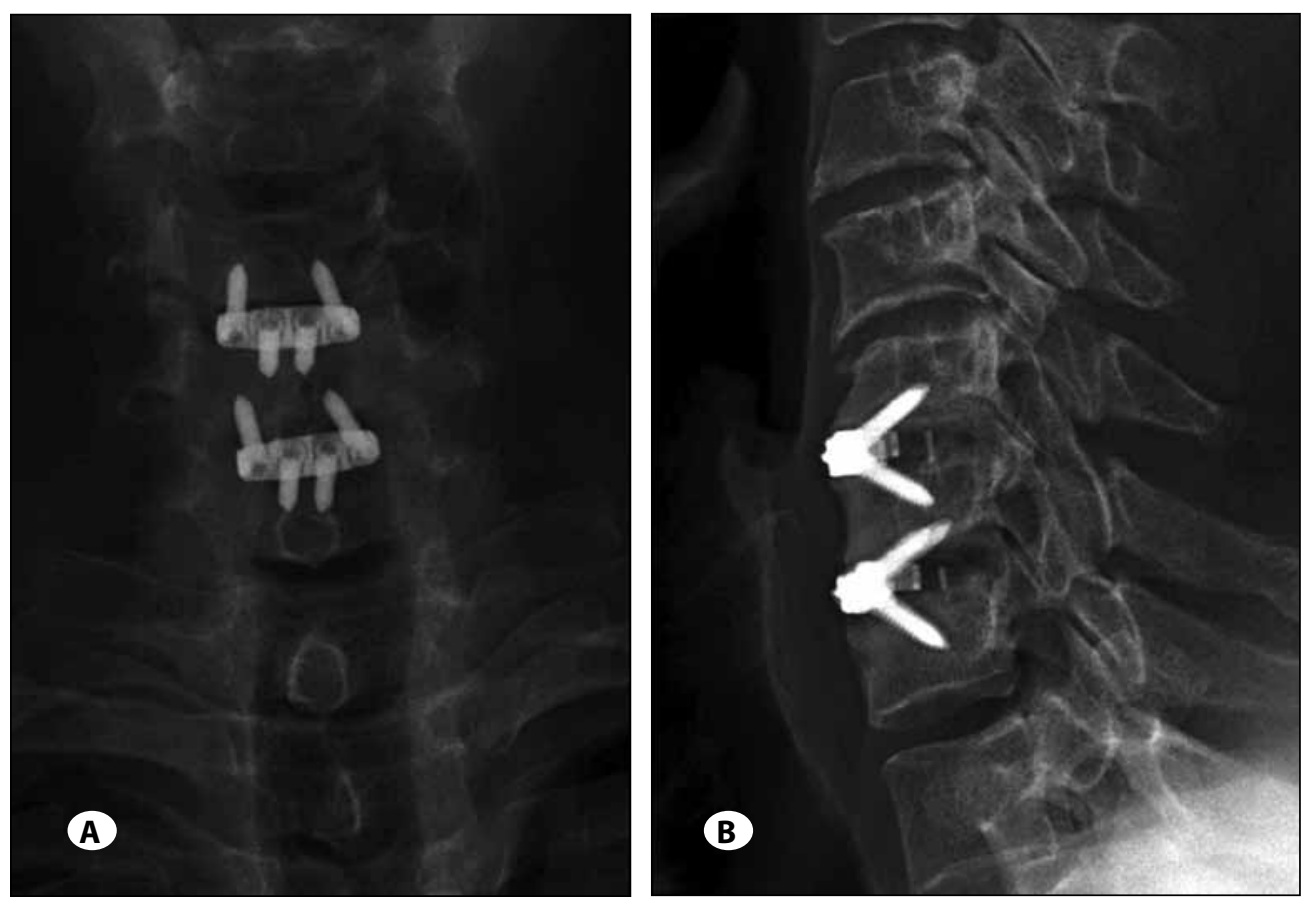

Figure 5: Postoperative anteroposterior (A) and lateral (B) plain X-rays at 3 months demonstrating no implant subsidence or screw pullout with radiological evidence of fusion. 
to follow the use of autologous bone grafts (3). Interbody fusion stops spur formation which prevents the buckling of the ligamentum flavum and consequently decreases postoperative pain (7). Furthermore, cage constructs accomplish internal fixation while simultaneously supplying structural support for the organic, fusion-producing bone material in and around the device thus permitting cancellous bone which is incorporated more quickly than a cortical allograft to serve as the fusion substrate (19).

Anterior cervical plating as a supplement to ACDF results in significantly higher incidence of fusion and decreased need for second surgery $(14,33)$. The addition of a plate is, however, not without side effects including dysphagia and implant-associated complications (34).

Anterior cervical plate design may be a factor in causing dysphagia; plates with lower profile and smoother surface are associated with lower incidence of dysphagia (23). Persistent long-term dysphagia can be caused by adhesions between posterior esophagus and the plate, patients with persistent dysphagia who undergone removal of anterior cervical plating were found to have extensive adhesions attaching the esophagus-trachea midline structures to the prevertebral fascia and anterior aperture in the plate. Instrumentation removal and operative lysis of adhesions resulted in significant improvement (12).

The incidence of dysphagia in our study is very similar to the study of Scholz et al (34) who used Zero-P implants in a series of 38 patients with a very low incidence of chronic dysphagia after the procedure and is much lesser than the incidence reported by other investigators $(6,15,32,33,35,45)$. The noprofile design of Zero-P implant avoids its contact with the soft tissue in front of the cervical spine and seems to prevent mechanical irritation of the esophagus and explain the low dysphagia rate (34).

In ACDF with anterior cervical plating, the screw-plate interface may lead to postoperative complications (34). Examples of such implant-associated complications include screw loosening, screw breakage, and plate breakage, screw pullout with or without migration into gastrointestinal tract $(8,13,16,24,27,37)$. Rarely, erosion of anterior cervical plate into pharynx with pharyngotracheal fistula (22) or pharyngocutaneous fistula may occur (31). Although rigid plate design with screws rigidly locked to the plate is thought to provide a better fixation for the treated spinal segment than a dynamic design in which the screws may slide when the graft is settling (37), Pitzen et al (28) recently found that dynamic cervical plate designs provide less implant complications, less implant failure-related revision surgery and faster speed of fusion compared with rigid cervical plates. Dynamic cervical plates were however associated with significantly higher rate of loss of segmental lordosis (28). We have noticed no implant-associated complications in any of our cases over a relatively long follow up period. Zero-P implants seem to combine the advantages of both rigid and dynamic plate designs and avoid their implant-associated complications.
Scholz and coworkers referred the lack of implant migration or screw loosening in their study to the design of the locking plate-screw interface of the Zero-P implant; the plate with an internal screw thread engages with the outer screw thread located in the head of the screw providing a safe, constrained, and angle-stable screw fixation (34).

Clinical outcome in our series was similar to the results reported in literature of ACDF with either anterior cervical plating $(1,10,20,21,25)$ or Zero-P implant fixation (34).

The Zero-P implant is a valid alternative to anterior cervical plating in patients undergoing ACDF and is characterized by a very low incidence of postoperative dysphagia and no implant-related complications detected in a relatively large number of patients over a minimum follow up period of one year. Longer follow up periods are needed for further confirmation of these results.

\section{REFERENCES}

1. Anderson DG, Albert TJ: Bone grafting, implants, and plating options for anterior cervical fusions. Orthop Clin North Am 33:317-328, 2002

2. Assietti R, Beretta F, Arienta C: Two-level anterior cervical discectomy and cage-assisted fusion without plates Neurosurg Focus 12 :article 3, 2002

3. Banwart JC, Asher MA, Hsssanein RS: Iliac crest bone graft harvest donor site morbidity. Spine 20:1055-1060,1995

4. Bartolomei J, Sonntag V: Anterior approach including cervical corpectomy. In:Winn H R (ed), Youmans' Neurological Surgery. Philadelphia: Saunders, 2004: 4431-4445

5. Bärlocher C, Barth A, Krauss J, Binggeli R, Seiler R: Comparative evaluation of microdiscectomy only, autograft Fusion, polymethylmethacrylate interposition, and threaded Titanium cage fusion for treatment of single-level cervical disc disease: A prospective randomized study in 125 patients. Neurosurg Focus 12: article 4, 2002

6. Bazaz R, Lee MJ, Yoo JU: Incidence of dysphagia after anterior cervical spine surgery: A prospective study. Spine 27: 2453-2458, 2002

7. Brooke NS, Rorke AW, King AT, Gullan RW: Preliminary experience of carbon fibre cage protheses for treatment of cervical spine disorders. Br J Neurosurg 11: 221-227,1997

8. Cagli S, Isik HS, Zileli M: Cervical screw missing secondary to delayed esophageal fistula: Case report. Turk Neurosurg 19:437-440, 2009

9. Carlsson AM: Assessment of chronic pain. I. Aspects of the reliability and validity of the visual analogue scale. Pain 16:87-101, 1983

10. Carr FA, Healy KM, Villavicencio AT, Nelson EL, Mason A, Burneikiene S, Hernández TD: Effect on clinical outcomes of patient pain expectancies and preoperative Mental Component Summary scores from the 36-Item Short Form Health Survey following anterior cervical discectomy and fusion. J Neurosurg Spine15:486-490, 2011

11. Cloward R: The anterior approach for removal of ruptured cervical disks. Neurosurgery 15:602-617, 1958 
12. Fogel GR, McDonnell MF: Surgical treatment of dysphagia after anterior cervical interbody fusion. Spine J 5:140-144, 2005

13. Fountas KN, Kapsalaki EZ, Machinis T, Robinson JS: Extrusion of a screw into the gastrointestinal tract after anterior cervical spine plating. J Spinal Disord Tech 19:199-203, 2006

14. Fraser JF, Härtl R: Anterior approaches to fusion of the cervical spine: A metaanalysis of fusion rates. J Neurosurg Spine 6: 298-303, 2007

15. Frempong-Boadu A, Houten JK, Osborn B, Opulencia J, Kells L, Guida DD, Le Roux PD: Swallowing and speech dysfunction in patients undergoing anterior cervical discectomy and fusion: A prospective, objective preoperative and postoperative assessment. J Spinal Disord Tech 15:362-368, 2002

16. Gazzeri R, Tamorri M, Faiola A, Gazzeri G: Delayed migration of a screw into the gastrointestinal tract after anterior cervical spine plating. Spine (Phila Pa 1976) 15(33):E268-271, 2008

17. Gokaslan ZL, Cooper PR: Treatment of disc and ligamentous diseases of the cervical spine by the anterior approach. In: Youmans J R, (ed), Neurological Surgery. Philadelphia: Saunders, 1996:2253-2261

18. Goolkasian P, Wheeler AH, Gretz SS: The neck pain and disability scale: Test-retest reliability and construct validity. Clin J Pain 18:245-250, 2002

19. Hacker R, Cauthen J, Gilbert T, Griffith S: A prospective randomized multicenter clinical evaluation of an anterior cervical fusion cage. Spine 25:2646-2654, 2000

20. Hermansen A, Hedlund R, Vavruch L, Peolsson A: A comparison between the carbon fiber cage and the Cloward procedure in cervical spine surgery: A ten- to thirteen-year follow-up of a prospective randomized study. Spine (Phila Pa 1976) 36:919925, 2011

21. Kim SW, Limson MA, Kim SB, Arbatin JJ, Chang KY, Park MS, Shin JH, Ju YS: Comparison of radiographic changes after ACDF versus Bryan disc arthroplasty in single and bi-level cases. Eur Spine J 18:218-231, 2009

22. Kuo YC, Levine MS: Erosion of anterior cervical plate into pharynx with pharyngotracheal fistula. Dysphagia 25: 334-337, 2010

23. Lee MJ, Bazaz R, Furey CG, Yoo J: Influence of anterior cervical plate design on Dysphagia: A 2-year prospective longitudinal follow-up study. J Spinal Disord Tech 18: 406-409, 2005

24. Lowery GL, McDonough RF: The significance of hardware failure in anterior cervical plate fixation. Patients with 2- to 7-year follow-up. Spine 23:181-186, 1998

25. Nabhan A, Ahlhelm F, Pitzen T, Steudel WI, Jung J, Shariat K, Steimer O, Bachelier F, Pape D: Disc replacement using ProDisc $C$ versus fusion: A prospective randomised and controlled radiographic and clinical study. Eur Spine J 16:423-430, 2007

26. Park JB, Cho YS, Riew KD: Development of adjacent-level ossification in patients with an anterior cervical plate. J Bone Joint Surg Am 87:558-563, 2005

27. Paramore CG, Dickmann CA, Sonntag VK: Radiographic and clinical follow-up review of Caspar plates in 49 patients. J Neurosurg 84:957-961, 1996
28. Pitzen TR, Chrobok J, Stulik J, Ruffing S, Drumm J, Sova L, Kucera R, Vyskocil T, Steudel WI: Implant complications, fusion, loss of lordosis, and outcome after anterior cervical plating with dynamic or rigid plates: two-year results of a multi-centric, randomized, controlled study. Spine (Phila Pa 1976) 34:641-646, 2009

29. Profeta G, de Falco R, lanniciello G, Profeta L, Cigliano A, Raja Al: Preliminary experience with anterior cervical and interbody titanium cage microdiscectomy(novus ct-ti) in patients with cervical disc disease. Surg Neurol 53:417-426, 2000

30. Robinson RA, Smith GW: Anterolateral cervical disc removal and interbody fusion for cervical disc syndrome. Bull Johns Hopkins Hosp 96:223-224, 1955

31. Sansur CA, Early S, Reibel J, Arlet V: Pharyngocutaneous fistula after anterior cervical spine surgery. Eur Spine J 18: 586-591, 2009

32. Saunders RL, Bernini PM, Shirreffs TG, Reeves AG: Central corpectomy for cervical spondylotic myelopathy: A consecutive series with long-term follow-up evaluation. J Neurosurg 74:163-170, 1991

33. Schneeberger AG, Boos N, Schwarzenbach O, Aebi M: Anterior cervical interbody fusion with plate fixation for chronic spondylotic radiculopathy: A 2- to 8-year follow-up. J Spinal Disord 12:215-220, 1999

34. Scholz M, Schnake KJ, Pingel A, Hoffmann R, Kandziora F: A new zero-profile implant for stand-alone anterior cervical interbody fusion. Clin Orthop Relat Res 469:666-673, 2011

35. Smith-Hammond CA, New KC, Pietrobon R, Curtis DJ, Scharver $\mathrm{CH}$, Turner DA: Prospective analysis of incidence and risk factors of dysphagia in spine surgery patients: Comparison of anterior cervical, posterior cervical, and lumbar procedures. Spine 29:1441-1446, 2004

36. Song KJ, Taghavi CE, Lee KB, Song JH, Eun JP: The efficacy of plate construct augmentation versus cage alone in anterior cervical fusion. Spine (Phila Pa 1976) 34:2886-2892, 2009

37. Stulik J, Pitzen TR, Chrobok J, Ruffing S, Drumm J, Sova L, Kucera R, Vyskocil T, Steudel WI: Fusion and failure following anterior cervical plating with dynamic or rigid plates: 6-months results of a multi-centric, prospective, randomized, controlled study. Eur Spine J 16:1689-1694, 2007

38. Thomé C, Krauss J, Zevgaridis D: A prospective clinical comparison of rectangular titanium cages and iliac crest autografts in anterior cervical discectomy and fusion. Neurosurg Rev 27:34-41, 2004

39. Thomé C, Leheta O, Krauss J, Zevgaridis D: A prospective randomized comparison of rectangular titanium cage fusion and iliac crest autograft fusion in patients undergoing anterior cervical discectomy. J Neurosurg Spine 4:1-9, 2006

40. Thorell W, Cooper J, Hellbusch L, Leibrock L: The long-term clinical outcome of patients undergoing anterior cervical discectomy with and without intervertebral bone graft place ment. Neurosurgery 43:268-274,1998

41. Ulrich $C$, Arand $M$, Nothwang J: Internal fixation on the lower cervical spine biomechanics and clinical practice of procedures and implants. Eur Spine J 10:88-100, 2001 
42. van Limbeek J, Jacobs WC, Anderson PG, Pavlov PW: A systematic literature review to identify the best method for a single level anterior cer vical interbody fusion. Eur Spine J 9:129-136, 2000

43. Wigfield CC, Nelson RJ: Non autologous interbody fusion materials in cervical spine surgery: How strong is the evidence to justify their use? Spine 26:687-694, 2001
44. Yang JY, Song HS, Lee M, Bohlman HH, Riew KD: Adjacent level ossification development after anterior cervical fusion without plate fixation. Spine (Phila Pa 1976) 34:30-33, 2009

45. Yue WM, Brodner W, Highland TR: Persistent swallowing and voice problems after anterior cervical discectomy and fusion with allograft and plating: A 5- to11-year follow-up study. Eur Spine J 14:677-682, 2005 